DOI https://doi.org/10.15407/csc.2021.05-06.025

UDC $004.942+623.454 .862$

O.G. REVUNOVA, Doctor of Engineering Sciences, Senior Researcher, International Research and Training Center for Information Technologies and Systems of the NAS and MES of Ukraine, Glushkov ave., 40, Kyiv, 03187 , Ukraine, egrevunova@gmail.com

O.V. TYSHCUK, Senior Software Engineer, Roku Inc., Kyiv, Ukraine, avtyshcuk@gmail.com

O.O. DESIATERYK, Ph.D. (Ph.-Mat.), Assistant professors, Taras Shevchenko National University of Kyiv, Glushkov ave., 4e, 03127 , Kyiv, Ukraine,

sasha.desyaterik@gmail.com

\title{
ON THE GENERALIZATION OF THE RANDOM PROJECTION METHOD FOR PROBLEMS OF THE RECOVERY OF OBJECT SIGNAL DESCRIBED BY MODELS OF CONVOLUTION TYPE
}

We considered the problem of object signals recovery in the systems where an input-output transformation is described by models of convolution type. To find a solution for such problem we built a generalization of the random projection method for twodimensional signals case. For the signal of the object which is described by the model based on convolution the stable method for its recovery has been developed.

Keywords: discrete ill-posed problem, convolution, regularization, random projection.

\section{Introduction}

In technical systems there is a common situation when transformation input-output is described by integral equation of convolution type. This situation accurse if object signal is recovered by the results of remote measurements. For example, in spectrometric tasks, for an image deblurring etc. Matrices of the discrete representation for output signal and the kernel of convolution are known. We need to find a matrix of the discrete representation of a signal of the object. The well known approach for solving this problem includes next steps. First, the kernel matrix has to be represented as the Kroneker product. Second, input-output transformation has to be presented with usage of Kroneker product matrices. Third, the matrix of the discrete representation of the object has to be found.
The object signal matrix estimation obtained with the help of pseudo inverting of Kroneker decomposition matrices is unstable. The instability of the object signal estimation in the case of usage of Kroneker decomposition matrices is caused by their discrete ill-posed matrix properties (condition number is big and the series of the singular numbers smoothly decrease to the zero). To find solutions of discrete ill-posed problems we developed methods based on the random projection and the random projection with an averaging by the random matrices. These methods provide stable solution with a small computational complexity.

We consider the problem of object signals recovering in the systems where an input-output transformation is described by the integral equation of a convolution. To find a solution for these 
problems we need to build a generalization for twodimensional signals case of the random projection method.

The purpose of this work is to develop a stable method for signal reconstruction for the case when the input-output transformation is described by convolution.

\section{Random Projection-based Regularization Approach}

In problems of statistics, machine learning and inverse problems theory, a situation often arises when the solution by existing methods is unstable, i.e. small changes in the input data (conditions of the problem) lead to a large change in the solution. Such unstable solutions are inaccurate and cannot be used in practice. To remove the instability of the solution, the regularization approach is use.

We developed an approach and different methods of the regularization based on the random projection. Our studies of the regularizing properties of random projection began in 2009 [1, 2]. Later other researchers began to explore the regularizing properties of random projection, for example, for classification problems [3] and machine learning [4], and, more recently, for solving inverse problems [5-7].

Since the approach of random projection, along with improving the accuracy of the solution by regularization, reduces the computational complexity of the solution. We developed algorithms that provide an accurate and fast solution for discrete inverse problems.

Let us consider in more detail the regularization of the inverse problem based on random projection.

In many practical applications, signal transformation is described by a linear model of the form, $\mathbf{y}=\mathbf{A x}+\boldsymbol{\varepsilon}$, where the matrix $\mathbf{A} \in \mathfrak{R}^{N \times N}$ and the measurement vector $\mathbf{y} \in \mathfrak{R}^{N}\left(\mathbf{y}=\mathbf{y}_{0}+\boldsymbol{\varepsilon}, \mathbf{y}_{0}=\mathbf{A x}\right)$ are known. The components of the noise vector $\boldsymbol{\varepsilon} \in \mathfrak{R}^{N}$ are realizations of independent Gaussian random variables with zero mean and variance $\sigma^{2}$. The signal vector $\mathbf{x} \in \Re^{N}$ has to be estimated.
The matrix A can be formed, for example, as a result of transformation of integral equation $\int_{a}^{b} K(t, s) \varphi(s) d s=f(t)$ kernel to the discrete form.

In the case when y contains noise and the series of singular numbers of the matrix A smoothly drops to zero (with A having a high conditionality number), the problem of estimating $\mathrm{x}$ is called the discrete ill-posed problem (DIP) [8, 9]. For DIP, the solution (estimate of signal $\mathrm{x}$ ) obtained on the basis of a pseudo-inversion as $\mathbf{x}^{*}=\mathbf{A}^{+} \mathbf{y}$, where $\mathbf{A}^{+}$ is a pseudoinverse is unstable and inaccurate. To overcome the instability and improve the accuracy of the solution, a regularization approach is used.

One of the approaches to ensuring the stability of solving ill-posed problems is the use of an integer regularization parameter, which is the number of summands in the model (linear with respect to parameters) approximating the original data.

Examples of method for obtaining a stable solution (estimation $\mathbf{x}^{*}$ ) are the next. First is truncated singular value decomposition [11-13]. Second is truncated QR decomposition [13].

Method developed by us is based on random projection [14-17]. This method also uses a number of summands of linear model as an integer regularization parameter [18].

To obtain solution based on random projection [19], both sides of the original equation are multiplied by the matrix $\mathbf{R}_{k} \in \mathfrak{R}^{k \times N}$ resulting in the equation

$\mathbf{R}_{k} \mathbf{A x}=\mathbf{R}_{k} \mathbf{y}$,
where $\left(\mathbf{R}_{k} \mathbf{A}\right) \in \mathfrak{R}^{k \times N},\left(\mathbf{R}_{k} \mathbf{y}\right) \in \mathfrak{R}^{k}$. The vector of the recovered signal is obtained as

$$
\mathbf{x}_{k}{ }^{*}=\left(\mathbf{R}_{k} \mathbf{A}\right)^{+} \mathbf{R}_{k} \mathbf{y} .
$$

As a random matrix $\mathrm{R}$ we use:

- the matrix $\mathbf{G}_{k} \in \mathfrak{R}^{k \times N}$ whose elements are realizations of a random variable with a Gaussian distribution, zero mean and unit variance;

- the matrix $\mathbf{Q}_{k} \in \mathfrak{R}^{k \times N}$ obtained by QR decomposition of $\mathbf{G A}$ matrix $(\mathbf{G A}=\mathbf{Q R})$;

- the matrix $\boldsymbol{\Omega}_{k} \in \mathfrak{R}^{k \times N}$ obtained by SVD decomposition of $\mathbf{G}$ matrix $\left(\mathbf{G}=\mathbf{\Omega} \boldsymbol{\Sigma} \mathbf{\Psi}^{\mathrm{T}}\right)$.

Experimental investigation showed the existence of the optimal number $k(k<N)$ of the random matrix rows which minimize the error of the true 
signal recovery: $e_{x}^{\prime}=\left\|\mathbf{x}-\mathbf{x}_{k} *\right\|^{2}$. The error of the input vector recovery and the output vector recovery (for RP) can be represented as a sum of two components (deterministic and stochastic):

$$
\begin{aligned}
& e_{x}=\mathrm{E}_{\varepsilon}\left\{e_{x}^{\prime}\right\}=\left\|\left(\left(\mathbf{R}_{k} \mathbf{A}\right)^{+} \mathbf{R}_{k} \mathbf{A}-\mathbf{I}\right) \mathbf{x}\right\|^{2}+ \\
& +\sigma^{2} \operatorname{trace}\left(\mathbf{R}_{k}^{\mathrm{T}}\left(\mathbf{R}_{k} \mathbf{A}\right)^{+\mathrm{T}}\left(\mathbf{R}_{k} \mathbf{A}\right)^{+} \mathbf{R}_{k}\right), \\
& e_{y}=\mathrm{E}_{\varepsilon}\left\{e_{y}^{\prime}\right\}=\left\|\left(\mathbf{A}\left(\mathbf{R}_{k} \mathbf{A}\right)^{+} \mathbf{R}_{k}-\mathbf{I}\right) \mathbf{y}_{0}\right\|^{2}+ \\
& +\sigma^{2} \operatorname{trace}\left(\mathbf{R}_{k}^{\mathrm{T}}\left(\mathbf{R}_{k} \mathbf{A}\right)^{+\mathrm{T}} \mathbf{A}^{\mathrm{T}} \mathbf{A}\left(\mathbf{R}_{k} \mathbf{A}\right)^{+} \mathbf{R}_{k}\right) .
\end{aligned}
$$

The deterministic component decrease with the increasing $k$ and the stochastic component increase [19].

Error components are represented as recursive expressions by the number of model components. Such representation (of input recovery error) helped to show analytically that stochastic component increases and deterministic component decreases when $k$ increase.

Experimental investigation of the dependency of input (and output) recovery error on the rows number in cases of different noise levels showed the minimum existence at $k<N$.

With noise levels' increasing the error minimum position is shifted to the smaller values of $k$. Studies have shown that the position $\left(k_{\mathrm{opt}}\right)$ of the input recovery error minimum and the output recovery error minimum are close.

We propose a criterion for choosing a model based on the approximation of the output recovery error. This criterion allows us to determine the complexity of the model close to optimal.

Computational complexity of a random projection solution $\mathrm{O}\left(n k^{2}\right)$ versus SVD complexity $\mathrm{O}\left(n^{3}\right)$. Note that $k<n$. Computational complexity of the incremental SVD algorithm realization $\mathrm{O}\left(n^{2} k\right)$ is greater then $\mathrm{O}\left(n^{2} k\right)$. Thus computational complexity of the random projecting $\mathrm{O}\left(n^{2} k\right)$ it the smallest of these three methods.

We improved the accuracy of the basic random projection method using analytical averaging by random matrices $[20,21]$.

Averaging over the realizations of matrices (in the experimental investigation) leads to a smoothing of the error dependence on $k$ and a decrease in the number of local minima. This makes it easier to find the optimal value of $k$ and increases the accuracy of the solution. Therefore, we did an analytical averaging over random matrices.

The following expression was averaged

$$
\begin{gathered}
\mathrm{E}_{\mathrm{R}}\left\{\mathrm{E}_{\varepsilon}\left\{e_{x}^{\prime}\right\}\right\}=\mathrm{E}_{\mathrm{R}}\left\{e_{x d}\right\}+\mathrm{E}_{\mathrm{R}}\left\{e_{x s}\right\}=\mathbf{x}^{\mathrm{T}} \mathbf{x}- \\
-\mathbf{x}^{\mathrm{T}} \mathbf{A}^{\mathrm{T}} \mathrm{E}_{\mathrm{R}}\left\{\mathbf{R}_{k}{ }^{\mathrm{T}}\left(\mathbf{R}_{k} \mathbf{A} \mathbf{A}^{\mathrm{T}} \mathbf{R}_{k}{ }^{\mathrm{T}}\right)^{-1} \mathbf{R}_{k}\right\} \mathbf{A} \mathbf{x}+ \\
+\sigma^{2} \operatorname{trace}\left(\mathrm{E}_{\mathrm{R}}\left\{\mathbf{R}_{k}{ }^{\mathrm{T}}\left(\mathbf{R}_{k} \mathbf{A} \mathbf{A}^{\mathrm{T}} \mathbf{R}_{k}{ }^{\mathrm{T}}\right)^{-1} \mathbf{R}_{k}\right\}\right) .
\end{gathered}
$$

The expression for the error after averaging over random matrices is the next

$$
\begin{aligned}
\mathrm{E}_{\mathrm{R}}\left\{e_{x}\right\} & =\mathbf{x}^{\mathrm{T}} \mathbf{x}-\mathbf{x}^{\mathrm{T}} \mathbf{A}^{\mathrm{T}} \mathbf{U} \mathbf{D}_{k} \mathbf{U}^{\mathrm{T}} \mathbf{A} \mathbf{x}+ \\
& +\sigma^{2} \operatorname{trace}\left(\mathbf{U D}_{k} \mathbf{U}^{\mathrm{T}}\right) .
\end{aligned}
$$

Further we obtained the explicit form of error components which arises after averaging over random matrices. That is, the bias and variance of the error that arising from averaging over random matrices:

$$
\begin{aligned}
& \mathrm{E}_{\mathrm{R}}\left\{e_{x}^{\prime}\right\}=\mathrm{E}_{\mathrm{R}}\left\{\left\|\mathbf{x}-\mathbf{x}^{*}\right\|^{2}\right\}=\left\|\mathbf{x}-\mathbf{x}^{\sim}\right\|^{2}+ \\
& +\mathrm{E}_{\mathrm{R}}\left\{\left\|\mathbf{x}^{\sim}-\left(\mathbf{R}_{k} \mathbf{A}\right)^{+} \mathbf{R}_{k} \mathbf{y}\right\|^{2}\right\}=e^{\mathrm{B}}+e^{\mathrm{v}},
\end{aligned}
$$

where $\mathbf{x}^{\sim}=\mathrm{E}_{\mathbf{R}}\left\{\left(\mathbf{R}_{k} \mathbf{A}\right)^{+} \mathbf{R}_{k} \mathbf{y}\right\}$ and

$$
\begin{aligned}
& e^{\mathrm{B}}=\left\|\mathbf{x}-\mathbf{A}^{\mathrm{T}} \mathbf{U} \mathbf{D}_{k} \mathbf{U}^{\mathrm{T}} \mathbf{y}\right\|^{2}, e^{\mathrm{B}}= \\
= & \mathbf{y}^{\mathrm{T}} \mathbf{U D}_{k} \mathbf{U}^{\mathrm{T}} \mathbf{y}-\left\|\mathbf{A}^{\mathrm{T}} \mathbf{U} \mathbf{D}_{k} \mathbf{U}^{\mathrm{T}} \mathbf{y}\right\|^{2} .
\end{aligned}
$$

The expression for the error of the random projection method obtained after analytical averaging over matrices is as follows

$$
\begin{gathered}
\mathrm{E}_{\varepsilon}\left\{\mathrm{E}_{\mathrm{R}}\left\{e_{x}^{\prime}\right\}\right\}=\mathrm{E}_{\varepsilon}\left\{e^{\mathrm{B}}\right\}+\mathrm{E}_{\varepsilon}\left\{e^{\mathrm{v}}\right\}= \\
=\mathrm{E}_{\varepsilon}\left\{\left\|\mathbf{x}-\mathbf{A}^{\mathrm{T}} \mathbf{U} \mathbf{D}_{k} \mathbf{U}^{\mathrm{T}} \mathbf{y}\right\|^{2}\right\}+ \\
+\mathrm{E}_{\varepsilon}\left\{\mathbf{y}^{\mathrm{T}} \mathbf{U} \mathbf{D}_{k} \mathbf{U}^{\mathrm{T}} \mathbf{y}-\left\|\mathbf{A}^{\mathrm{T}} \mathbf{U} \mathbf{D}_{k} \mathbf{U}^{\mathrm{T}} \mathbf{y}\right\|^{2}\right\},
\end{gathered}
$$

where error components are the bias and the variance. Note that the expression for the variance includes only known values: the output vector and matrix factorizations associated with the original matrix. Therefore, the error can be reduced by the variance component value.

If we recover the input vector as $\mathbf{x}^{*}=\mathbf{A}^{\mathrm{T}} \mathbf{U D} \mathbf{U}^{\mathrm{T}} \mathbf{y}$ then error of the output vector recovery decreases by the variance value (which arises after averaging over random matrices).

The solution method for DIP in which solution obtained as follows $\mathbf{x}_{\text {DRP }}^{*}=\mathbf{A}^{\mathrm{T}} \mathbf{U} \mathbf{D}_{k} \mathbf{U}^{\mathrm{T}} \mathbf{y}$ we call "deterministic random projection method" or shortly DRP. The DRP method error is smaller than the error of original random projection method RP. 


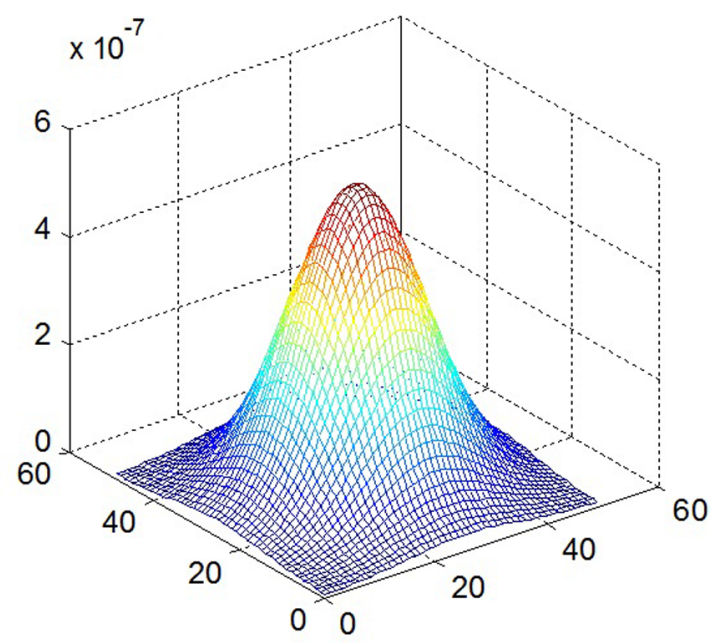

Fig. 1. Example of point spread function $K$

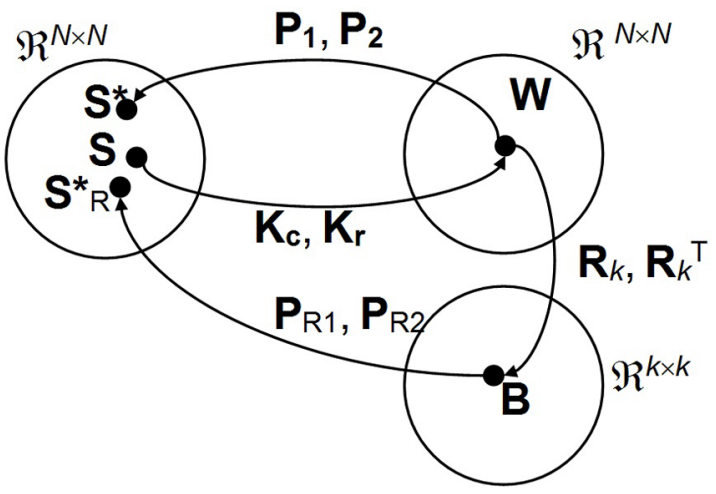

Fig. 2. The scheme of actions for $\mathbf{P}_{1}, \mathbf{P}_{2}, \mathbf{K}_{\mathrm{c}}, \mathbf{K}_{\mathrm{r}}, \mathbf{R}, \mathbf{P}_{\mathrm{R} 1}, \mathbf{P}_{\mathrm{R} 2}$

Also we should note that the DRP method error dependency on number of random matrix rows is smooth. On the contrary singular decomposition TSVD method error has local minima. Therefore, finding the optimal DRP solution is made easier.

\section{Random Projection Approach Gene- ralization to the Case when Input- Output Transformation is Described by Convolution}

Consider the situation when input-output transformation is described by integral equation of convolution type. This situation occurs if object signal is recovered by the results of remote measurements. For example, it arises in spectrometric tasks and in image deblurring tasks.

Let output matrix $\mathrm{W}$ be formed as follows $\mathbf{W}=\operatorname{conv}(\mathbf{S}, \mathbf{K})$,

where conv is a convolution operation, $\mathbf{S}$ is a matrix of discrete representation for two-dimensional input signal $\sigma(x, y), \mathbf{K}$ is a matrix of discrete representation of the convolution kernel $K(x, y)$. An example of $K$ is at the figure 1.

Matrices of discrete representation for output signal and for convolution kernel (point spread function) are known. We need to find a matrix of discrete representation of object signal $\mathbf{S}$.

Matrix of kernel discrete representation can be represented as follows $\mathbf{K}=\mathbf{K}_{\mathrm{r}} \otimes \mathbf{K}_{\mathrm{c}}$, where $\otimes$ is a Kroneker product. Using this matrix $\mathbf{K}$ representation we can write the convolution of $\mathbf{S}$ and $\mathbf{K}$ in a form of the product of matrices:

$$
\mathbf{W}=\mathbf{K}_{\mathrm{c}} \mathbf{S} \mathbf{K}_{\mathrm{r}}^{\mathrm{T}}, \mathbf{K}_{\mathrm{c}} \in \mathfrak{R}^{N \times N}, \mathbf{K}_{\mathrm{r}} \in \mathfrak{R}^{N \times N} .
$$

If estimation $\mathbf{S}$ is obtained as $\mathbf{S} *=\mathbf{K}_{\mathrm{c}}{ }^{+} \mathbf{W}\left(\mathbf{K}_{\mathrm{r}}^{\mathrm{T}}\right)^{+}$ then solution is unstable. That is why very big error in estimation $\mathbf{S}$ arises. Instability of the estimation $\mathbf{S}$ obtained with usage of pseudo inverting of matrices $\mathbf{K}_{\mathbf{c}}$ and $\mathbf{K}_{\mathbf{r}}^{\mathbf{T}}$ it caused by DIP properties of these matrices.

To obtain a stable solution the singular decomposition of matrices $\mathbf{K}_{c}$ and $\mathbf{K}_{r}$ $\left(\mathbf{K}_{\mathrm{c}}=\mathbf{U}_{\mathrm{c}} \sum_{\mathrm{c}} \mathbf{V}_{\mathrm{c}}^{\mathrm{T}}, \mathbf{K}_{\mathrm{r}}=\mathbf{U}_{\mathrm{r}} \sum_{\mathrm{r}} \mathbf{V}_{\mathrm{r}}^{\mathrm{T}}\right)$ is used. To get a close to optimal estimation of the matrix $\mathbf{S}$ the $k$ components of singular decomposition are used as follows

$$
\mathbf{S}_{\mathrm{SVD}} *=\mathbf{V}_{\mathrm{ck}} \Sigma_{\mathrm{ck}}{ }^{-1} \mathbf{U}_{\mathrm{ck}}{ }^{\mathrm{T}} \mathbf{W} \mathbf{U}_{\mathrm{rk}} \Sigma_{\mathrm{r} k}{ }^{-1} \mathbf{V}_{\mathrm{rk}}{ }^{\mathrm{T}} .
$$

We will obtain a stable solution based on random projections.

To get such solution we project matrices $\mathbf{K}_{\mathbf{c}}, \mathbf{K}_{\mathbf{r}}$ (Fig. 1)

$\mathbf{K}_{\mathrm{c}}=\mathbf{R}_{k} \mathbf{K}_{\mathrm{c}}, \mathbf{K}_{\mathrm{r}}=\mathbf{K}_{\mathrm{r}} \mathbf{R}_{k}, \mathbf{K}_{\mathrm{c}} \in \mathfrak{R}^{k \times N}, \mathbf{K}_{\mathrm{r}} \in \mathfrak{R}^{k \times N}$, and project the output matrix $\mathbf{W}$

$$
\mathbf{B}=\mathbf{R}_{k} \mathbf{W} \mathbf{R}_{k}{ }^{\mathrm{T}}, \mathbf{B} \in \mathfrak{R}^{k \times k} .
$$

Convolution equation after projecting turn into the next

$$
\mathbf{R}_{k} \mathbf{W} \mathbf{R}_{k}{ }^{\mathrm{T}}=\mathbf{R}_{k} \mathbf{K}_{\mathrm{c}} \mathbf{S}\left(\mathbf{K}_{\mathrm{r}} \mathbf{R}_{k}\right)^{\mathrm{T}} .
$$

Estimation $\mathbf{S}$ can be obtained based on random projection as follows

$$
\mathbf{S}_{\mathrm{RP}}{ }^{*}=\left(\mathbf{R}_{k} \mathbf{K}_{\mathrm{c}}\right)^{+} \mathbf{R}_{k} \mathbf{W} \mathbf{R}_{k}{ }^{\mathrm{T}}\left(\mathbf{K}_{\mathrm{r}}^{\mathrm{T}} \mathbf{R}_{k}{ }^{\mathrm{T}}\right)^{+}
$$




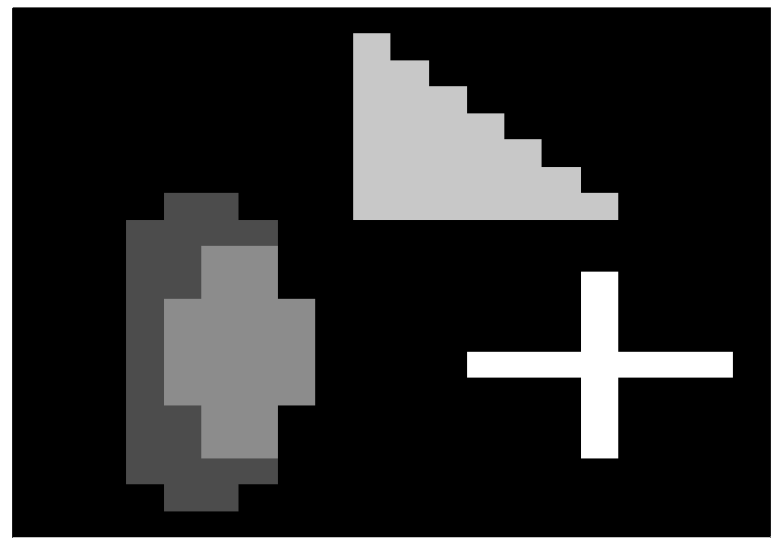

a) Input image

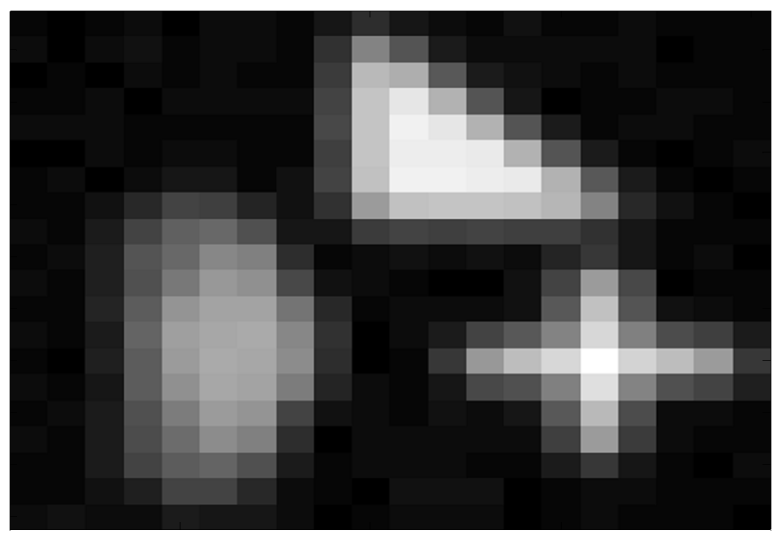

b) Blurred image

Fig. 3. Test input image $a$ ) and the result of its blurring $b$ )

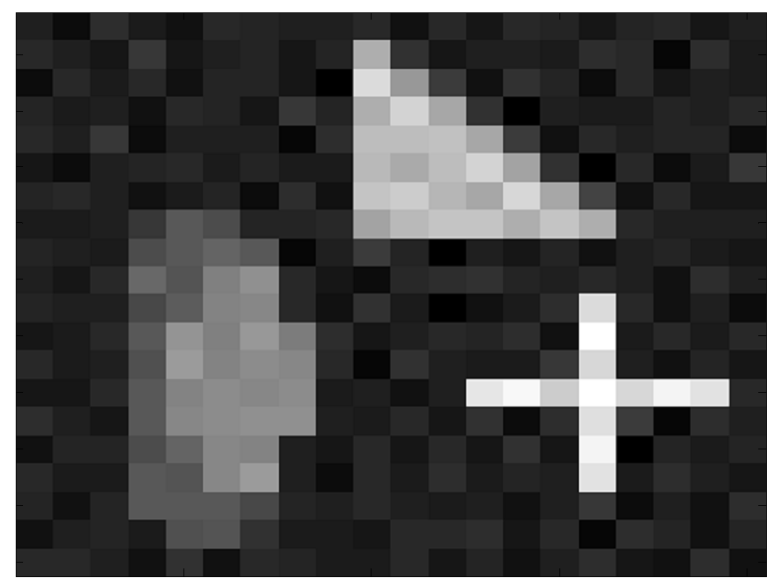

a) random projection

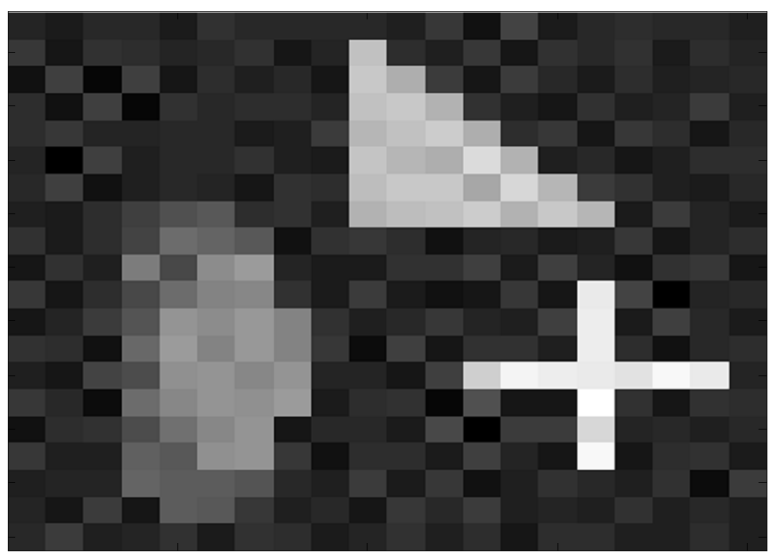

c) GCV

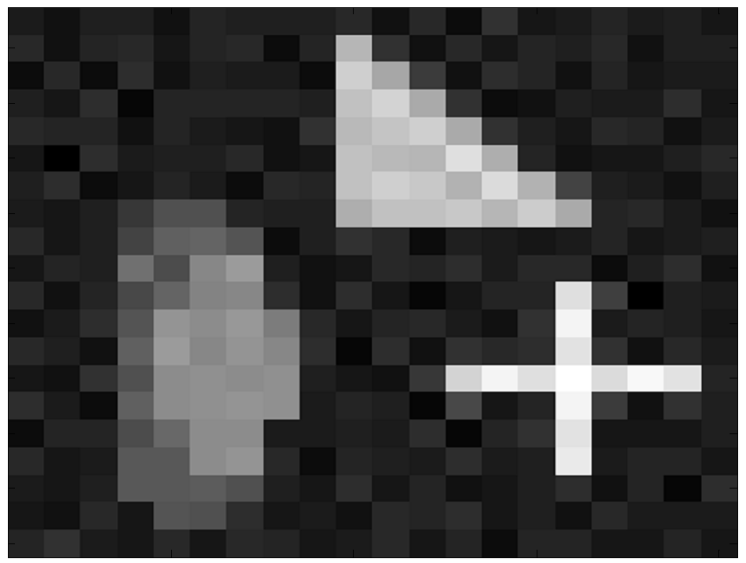

b) $\lambda_{\mathrm{opt}}$

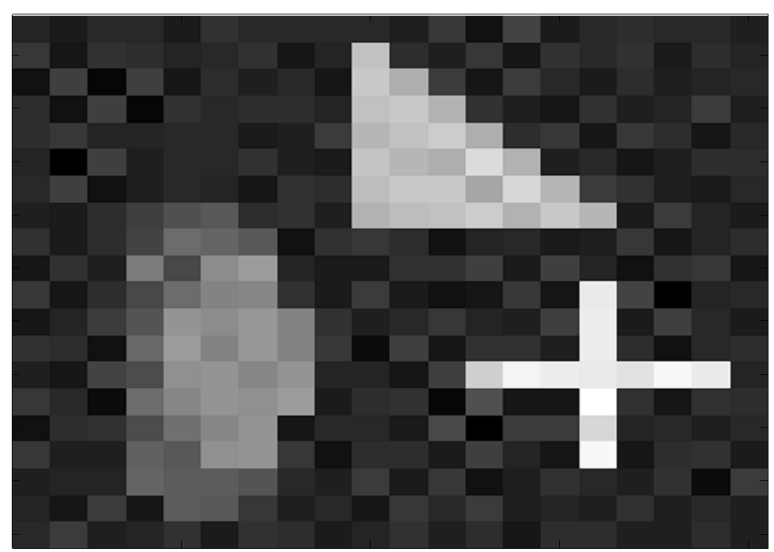

d) $L$-curve

Fig. 4. Recovery results 
Table 1. Recovery error of a two-dimensional signal

\begin{tabular}{|c|c|c|c|c|}
\hline Random projection & \multicolumn{4}{|c|}{ Ridge regression } \\
\hline DRP & $\lambda_{\text {opt }}$ & GCV & $L$-curve & DSC \\
\hline 18,34 & 15,7 & 23,19 & 23,2 & 19,56 \\
\hline
\end{tabular}

and based on random projection with averaging as follows

$$
\mathbf{S}_{\mathrm{DRP}} *=\mathrm{E}_{\mathrm{R}}\left\{\left(\mathbf{R}_{k} \mathbf{K}_{\mathrm{c}}\right)^{+} \mathbf{R}_{k}\right\} \mathbf{W} \mathrm{E}_{\mathrm{R}}\left\{\mathbf{R}_{k}{ }^{\mathrm{T}}\left(\mathbf{K}_{\mathrm{r}}^{\mathrm{T}} \mathbf{R}_{k}{ }^{\mathrm{T}}\right)^{+}\right\} \text {. }
$$

For the method of two-dimensional signal recovery based on truncated singular value decomposition we write operators $\mathbf{P}_{1}$ and $\mathbf{P}_{2}$ which transform $\mathbf{W}$ to $\mathbf{S}^{*}$ as follows

$$
\mathbf{P}_{1}=\mathbf{V}_{\mathrm{ck}} \Sigma_{\mathrm{ck}}{ }^{-1} \mathbf{U}_{\mathrm{ck}}{ }^{\mathrm{T}}, \mathbf{P}_{2}=\mathbf{U}_{\mathrm{rk}} \sum_{\mathrm{r} k}{ }^{-1} \mathbf{V}_{\mathrm{r} k}^{\mathrm{T}} .
$$

For the method of two-dimensional signal recovery based on the random projection we write operators $\mathbf{P}_{\mathrm{R} 1}$ and $\mathbf{P}_{\mathrm{R} 2}$ which transform $\mathbf{B}$ to $\mathbf{S}^{*}$ as follows

$$
\mathbf{P}_{\mathrm{R} 1}=\left(\mathbf{R}_{k} \mathbf{K}_{\mathrm{c}}\right)^{+} \mathbf{R}_{k}, \mathbf{P}_{\mathrm{R} 2}=\mathbf{R}_{k}{ }^{\mathrm{T}}\left(\mathbf{K}_{\mathrm{r}}^{\mathrm{T}} \mathbf{R}_{k}{ }^{\mathrm{T}}\right)^{+},
$$

and for the random projection with averaging

$$
\begin{gathered}
\mathbf{P}_{\mathrm{ER} 1}=\mathrm{E}_{\mathrm{R}}\left\{\left(\mathbf{R}_{k} \mathbf{K}_{\mathrm{c}}\right)^{+} \mathbf{R}_{k}\right\}, \\
\mathbf{P}_{\mathrm{ER} 2}=\mathrm{E}_{\mathrm{R}}\left\{\mathbf{R}_{k}{ }^{\mathrm{T}}\left(\mathbf{K}_{\mathrm{r}}{ }^{\mathrm{T}} \mathbf{R}_{k}{ }^{\mathrm{T}}\right)^{+}\right\} .
\end{gathered}
$$

Let's transform the expression for estimation $\mathbf{S}_{\text {DRP }}{ }^{*}$ based on the random projection with averaging as follows

$\mathbf{S}_{\mathrm{DRP}} *=\mathrm{E}_{\mathrm{R}}\left\{\left(\mathbf{R}_{k} \mathbf{K}_{\mathrm{c}}\right)^{+} \mathbf{R}_{k}\right\} \mathbf{K}_{\mathrm{c}} \mathbf{S} \mathbf{K}_{\mathrm{r}}^{\mathrm{T}} \mathrm{E}_{\mathrm{R}}\left\{\mathbf{R}_{k}{ }^{\mathrm{T}}\left(\mathbf{K}_{\mathrm{r}}^{\mathrm{T}} \mathbf{R}_{k}{ }^{\mathrm{T}}\right)^{+}\right\}$.

Present $\mathbf{P}_{\mathrm{R} 1}$ and $\mathbf{P}_{\mathrm{R} 2}$ as follows

$$
\begin{gathered}
\mathbf{P}_{\mathrm{R} 1}=\left(\mathbf{R}_{k} \mathbf{K}_{\mathrm{c}}\right)^{+} \mathbf{R}_{k}=\mathbf{K}_{\mathrm{c}}{ }^{T} \mathbf{R}_{k}{ }^{T}\left(\mathbf{R}_{k} \mathbf{K}_{\mathrm{c}} \mathbf{K}_{\mathrm{c}}{ }^{T} \mathbf{R}_{k}{ }^{T}\right)^{-1} \mathbf{R}_{k}, \\
\mathbf{P}_{\mathrm{R} 2}=\mathbf{R}_{k}{ }^{\mathrm{T}}\left(\mathbf{K}_{\mathrm{r}}{ }_{\mathrm{r}} \mathbf{R}_{k}{ }^{\mathrm{T}}\right)^{+}=\mathbf{R}_{k}{ }^{T}\left(\mathbf{R}_{k} \mathbf{K}_{\mathrm{r}} \mathbf{K}_{\mathrm{r}}{ }^{T} \mathbf{R}_{k}{ }^{T}\right)^{-1} \mathbf{R}_{k} \mathbf{K}_{\mathrm{r}} .
\end{gathered}
$$

Further we average

$$
\begin{aligned}
& \mathbf{P}_{\mathrm{ER} 1}=\mathrm{E}_{\mathrm{R}}\left\{\mathbf{P}_{\mathrm{R} 1}\right\}=\mathrm{E}_{\mathrm{R}}\left\{\left(\mathbf{R}_{k} \mathbf{K}_{\mathrm{c}}\right)^{+} \mathbf{R}_{k}\right\}= \\
& =\mathbf{K}_{\mathrm{c}}{ }^{T} \mathrm{E}_{\mathrm{R}}\left\{\mathbf{R}_{k}{ }^{T}\left(\mathbf{R}_{k} \mathbf{K}_{\mathrm{c}} \mathbf{K}_{\mathrm{c}}{ }^{T} \mathbf{R}_{k}{ }^{T}\right)^{-1} \mathbf{R}_{k}\right\} .
\end{aligned}
$$

Since $\mathbf{K}_{\mathrm{c}}=\mathbf{U}_{\mathrm{c}} \sum_{\mathrm{c}} \mathbf{V}_{\mathrm{c}}^{\mathrm{T}}$ and $\mathbf{K}_{\mathrm{c}} \mathbf{K}_{\mathrm{c}}{ }^{T}=\mathbf{U}_{\mathrm{c}} \mathbf{Z}^{2} \mathbf{U}_{\mathrm{c}}^{\mathrm{T}}$ we get the next

$$
\begin{aligned}
\mathbf{P}_{\mathrm{ER} 1} & =\mathbf{K}_{\mathrm{c}}{ }^{T} \mathrm{E}_{\mathrm{R}}\left\{\mathbf{R}_{k}{ }^{T}\left(\mathbf{R}_{k} \mathbf{U}_{\mathrm{c}} \mathbf{Z}^{2} \mathbf{U}_{\mathrm{c}}{ }^{\mathrm{T}} \mathbf{R}_{k}{ }^{T}\right)^{-1} \mathbf{R}_{k}\right\}= \\
& =\mathbf{K}_{\mathrm{c}}{ }^{T} \mathbf{U}_{\mathrm{c}} \mathrm{E}_{\mathrm{R}}\left\{\mathbf{R}_{k}{ }^{T}\left(\mathbf{R}_{k} \mathbf{Z}^{2} \mathbf{R}_{k}{ }^{T}\right)^{-1} \mathbf{R}_{k}\right\} \mathbf{U}_{\mathrm{c}}{ }^{\mathrm{T}} .
\end{aligned}
$$

Since we obtained a singular value decomposition of $\mathbf{K}_{\mathrm{c}}$ and taking into account that $\mathrm{E}_{\mathbf{R}}\left\{\mathbf{R}_{k}^{T}\left(\mathbf{R}_{k} \mathbf{Z}^{2} \mathbf{R}_{k}{ }^{T}\right)^{-1} \mathbf{R}_{k}\right\}=\mathbf{D}_{k}$ we get:

$$
\mathbf{P}_{\mathrm{ERI}}=\mathbf{V}_{\mathrm{c}} \Sigma_{\mathrm{c}}^{\mathrm{T}} \mathbf{D}_{k} \mathbf{U}_{\mathrm{c}}{ }^{\mathrm{T}} \text {. }
$$

Similarly

$$
\begin{gathered}
\mathbf{P}_{\mathrm{ER} 2}=\mathbf{U}_{\mathrm{r}} \mathrm{E}_{\mathrm{R}}\left\{\mathbf{R}_{k}{ }^{T}\left(\mathbf{R}_{\mathrm{k}} \mathbf{Z}^{2} \mathbf{R}_{k}{ }^{T}\right)^{-1} \mathbf{R}_{k}\right\} \mathbf{U}_{\mathrm{r}}^{\mathrm{T}} \mathbf{U}_{\mathrm{r}} \sum_{\mathrm{r}} \mathbf{V}_{\mathrm{r}}^{\mathrm{T}}= \\
=\mathbf{U}_{\mathrm{r}} \mathbf{D}_{k} \sum_{\mathrm{r}} \mathbf{V}_{\mathrm{r}}^{\mathrm{T}} .
\end{gathered}
$$

After substitution $\mathbf{P}_{\mathrm{ER} 1}$ and $\mathbf{P}_{\mathrm{ER} 2}$ in $\mathbf{S}_{\mathrm{DRP}}$ we get the next

$$
\mathbf{S}_{\mathrm{DRP}} *=\mathbf{V}_{\mathrm{c}} \mathbf{D}_{k}^{\mathrm{c}} \mathbf{V}_{\mathrm{c}}^{\mathrm{T}} \mathbf{S} \mathbf{V}_{\mathrm{r}} \mathbf{D}_{k}^{\mathrm{r}} \mathbf{V}_{\mathrm{r}}^{\mathrm{T}},
$$

where $\mathbf{D}^{\mathrm{c}}{ }_{k}=\Sigma_{\mathrm{c}}{ }_{\mathrm{c}} \mathbf{D}_{k} \Sigma_{\mathrm{c}}, \mathbf{D}^{\mathrm{r}}{ }_{k}=\mathbf{S}_{\mathrm{r}} \mathbf{D}_{k} \mathbf{S}_{\mathrm{r}}{ }^{\mathrm{T}}$ are diagonal matrices.

We calculate two-dimensional signal recovery error as follows

$$
\begin{gathered}
\mathrm{e}=\left\|\mathbf{S}_{\mathrm{RP}}{ }^{*}-\mathbf{S}\right\|_{\mathrm{F}}^{2} . \\
\mathrm{e}=\left\|\mathbf{S}_{\mathrm{RP}}{ }^{2}\right\|_{\mathrm{F}}^{2}+\|\mathbf{S}\|_{\mathrm{F}}^{2}-2<\mathbf{S}_{\mathrm{RP}} *, \mathbf{S}>_{\mathrm{F}}, \\
\mathrm{e}=\operatorname{trace}\left(\mathbf{S}_{\mathrm{RP}} *^{\mathrm{T}} \mathbf{S}_{\mathrm{RP}}{ }^{*}\right)+\operatorname{trace}\left(\mathbf{S}^{\mathrm{T}} \mathbf{S}\right)- \\
-2 \operatorname{trace}\left(\mathbf{S}_{\mathrm{RP}} *^{\mathrm{T}} \mathbf{S}\right) .
\end{gathered}
$$

\section{Example of Use in Technical Tasks}

We consider an example of solving the recovery of blurred image task [22, 23]. Here we implement the approach of the inverse task regularization based on random projections generalized for the twodimensional input signal case.

The test input image and the result of its blur are shown in Fig. 3. The task is to recover the original image as accurately as possible on the basis of blurred image data.

For the image recovery task we did next experiments. We studied dependency of signal recovery error value on the regularization parameter by methods based on random projections (with regularization parameter $k$ ) and based on singular value decomposition (ridge regression with regularization parameter $\lambda$ ).

Regularization parameter for ridge regression was calculated by methods of generalized discrepancy, $L$-curve and generalized cross validation. Results obtained by generalized discrepancy method 

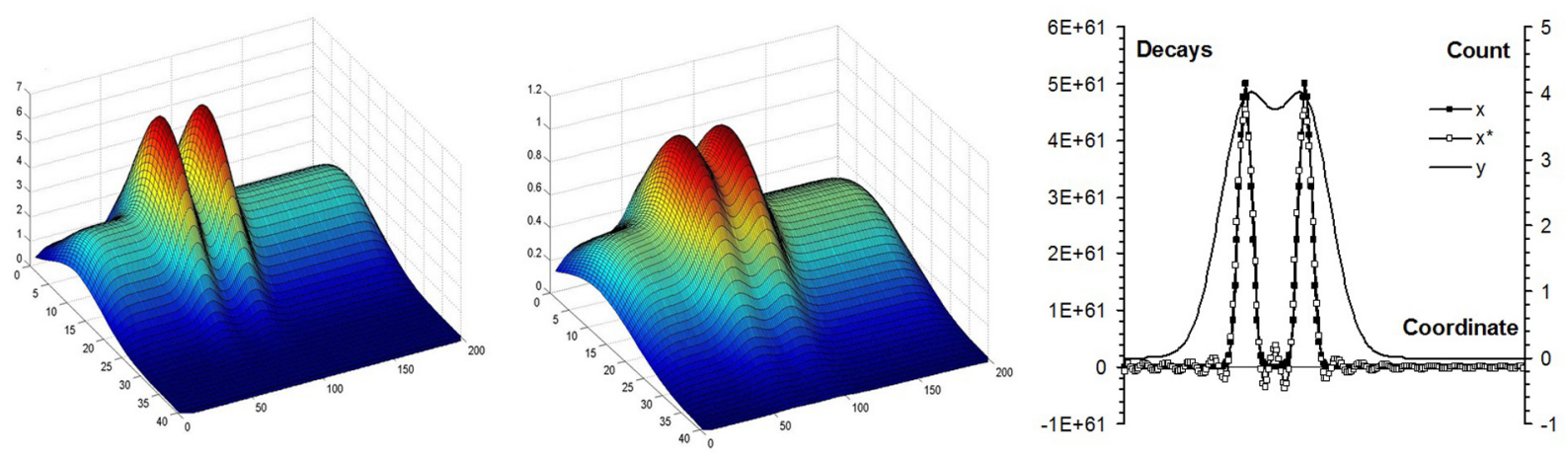

Fig. 5. Object signal (left) output signal (centre)

Table 2. The error of a two-dimensional signal recovery by DRP and TSVD methods

\begin{tabular}{|c|c|c|c|c|c|c|}
\hline \multicolumn{5}{|c|}{ TSVD } & \multicolumn{3}{c|}{ DRP } \\
\hline$\sigma^{2}$ & $10^{-2}$ & $10^{-3}$ & $10^{-4}$ & $10^{-2}$ & $10^{-3}$ & $10^{-4}$ \\
\hline $\mathrm{M}\{\mathrm{e}\}$ & 0,072 & 0,018 & 0,005 & 0,072 & 0,027 & 0,008 \\
\hline $\operatorname{Std}\{\mathrm{e}\}$ & 0,0106 & 0,006 & 0,0004 & 0,007 & 0,004 & 0,001 \\
\hline $\mathrm{M}\{\mathrm{k}\}$ & 6,46 & 11,37 & 19,27 & 6,4 & 13 & 23,1 \\
\hline $\operatorname{Std}\{\mathrm{k}\}$ & 1,10 & 1,04 & 1,82 & 0,52 & 0,82 & 0,32 \\
\hline
\end{tabular}

should be considered as ideal because information about noise vectors is used.

Optimal values of regularization parameters $\left(k_{\mathrm{opt}}\right)$ for random projections and $\lambda_{\mathrm{opt}}$ for ridge regression) were calculated by search. Values of recovery error of a two-dimensional signal for random projection and ridge regression methods are presented in the table 1.

The table shows that a two-dimensional signal recovery by random projection method is the most accurate at the level of ideal values for ridge regression.

Further we consider another example of the problem in which input-output transformation is described by convolution. This is a problem of object signal recovery by the results of remote gamma spectrometric measurements.

Connection between a signal radiated by object (input signal) and measuring system output signal is described by convolution of the function and the point spread function

$$
\begin{gathered}
K\left(x, y, x^{d}, y^{d}\right)=s q\left(x^{d}, y^{d}, x, y\right) \exp (-\mu \rho) / 4 \pi \rho^{2}, \\
\rho=\left(\left(h^{d}-h(x, y)\right)^{2}+\left(x^{d}-x\right)^{2}+\left(y^{d}-y\right)^{2}\right)^{1 / 2}, \\
q\left(x^{d}, y^{d}, x, y\right)=\left(h^{d}-h(x, y)\right) / \rho,
\end{gathered}
$$

where $h^{d}$ is a parameter, $s$ is a calibration multiplier.
A two-dimensional output signal does not reflect detailed object radiated signal. In the other words the image of output signal is distorted changed towards smoothing. The larger the parameter hd, the more the true object signal is smoothed (Fig. 5).

The figure 5 (right) shows a section of a twodimensional signal (matrix row) for output signal $\mathrm{y}$, true object signal $\mathrm{x}$ and recovered signal $\mathrm{x}$.

We did an experimental study of the accuracy of object signal recovery by the results of remote measurements using TSVD and DRP methods. Numerical modeling was made for the problem of "doublet recovery" [24].

We calculated average value of solution error, mean value of $k$ and their standard deviation for three levels of self noise. Modeling results are shown in the table 2.

For the model with the optimal complexity the two-dimensional recovery error obtained by DRP method is close to the TSVD method especially at the noise level 10-2. This indicates that the proposed generalization of the random projection method to the case of a two-dimensional signal is very promising. 


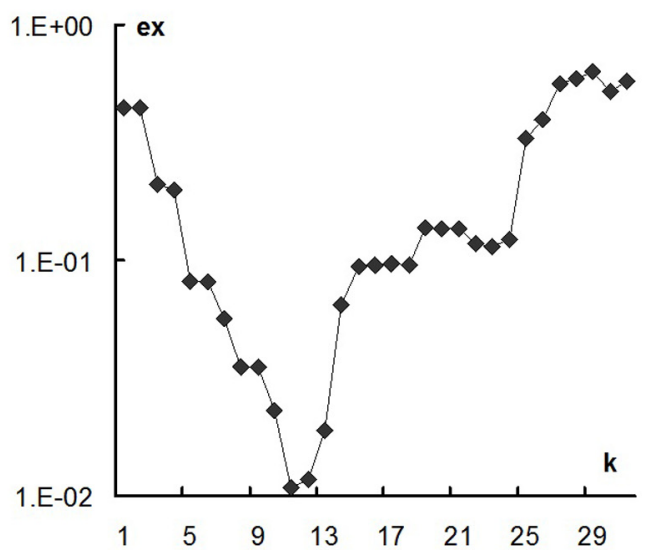

Fig. 6. $a$-Dependency of the solution error by $k$ when $\sigma^{2}=10^{-3}$

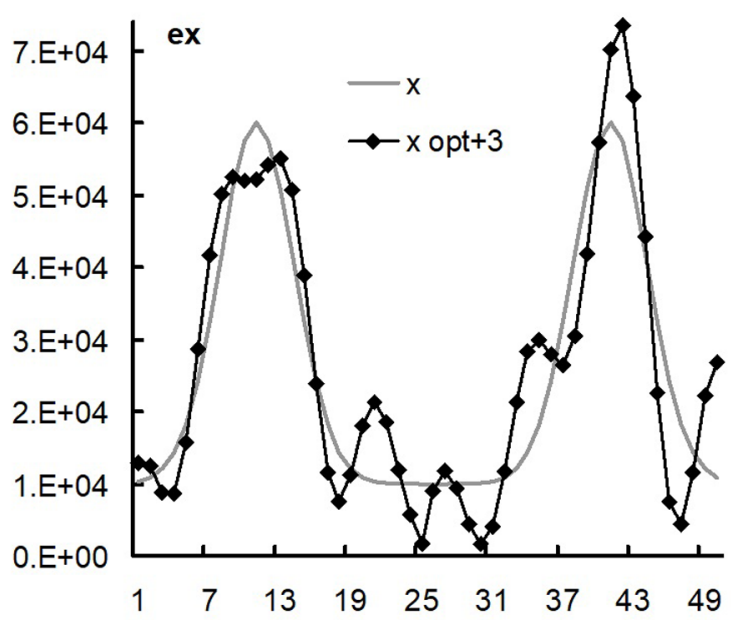

Fig. 7. The recovered signal shape at the point $k=k_{\mathrm{opt}}+3$

At the Fig. 6,a we show the dependency of the two-dimensional function $\sigma(x, y)$ recovery error on the number of rows in the random matrix. This dependency is obtained in the result of numerical modelling. We modelled it for $h_{d}=100$ at the noise $\sigma^{2}=10^{-3}$. At the Fig. $6, b$ we show the true object signal (the matrix $\mathbf{S}$ row) and the signal recovered by DRP method (matrix $\mathbf{S}_{\mathrm{DRP}}{ }^{*}$ row) at $k=k_{\mathrm{opt}}$. The signal form recovery accuracy is high in this case. Dependency $e_{x}(k)$ grow fast on the right side

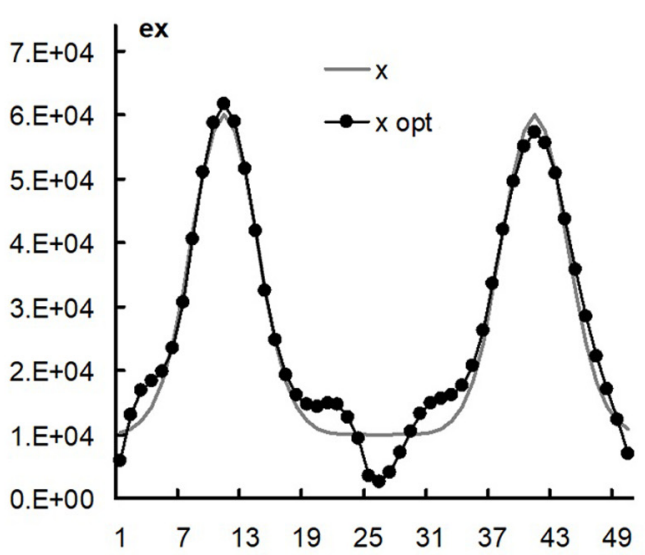

$b-$ The form of the recovered signal at $k=k_{\text {opt }}$

from the optimum point. That is why at the point $k=k_{\text {opt }}+3$ the error value increases by almost an order of magnitude compared to the optimal. Thus the shape of the recovered signal is significantly changed compared to the shape of the true signal (Fig.7).

This example clearly demonstrates how the accuracy of determining the regularization parameter kopt affects the accuracy of signal recovery. Development and research of an approach to determining the regularization parameter is a direction for further research.

\section{Conclusions}

We developed the method of a stable recovery of object signal for the case in which an input-output transformation is described by the integral equation of a convolution. The stable estimation of the object signal is provided by Kroneker decomposition of the kernel matrix of convolution, computation of random projections for Kroneker factorization matrices and a selection of the optimal dimension of a projector matrix. The method is illustrated by its application in technical problems.

The direction of further research is the development of methods for selection of the optimal dimension of the projector matrix. 


\section{REFERENCES}

1. Revunova E.G., Rachkovskiy D.A., 2009. "Using randomized algorithms for solving discrete ill-posed problems”, Intern. Journal Information Theories and Applications, 2 (16), pp. 176-192.

2. Revunova E.G., Rachkovskiy D.A., 2009. "Povysheniye tochnosti resheniya obratnoy zadachi s ispolzovaniyem sluchaynykh proyektsiy", Proceedings of the XV International conference "Knowledge-Dialogue-Solution" (KDS-2 2009), Kiev, Ukraine, pp. 93-98. [Ревунова Е. Г., Рачковский Д. А. Повышение точности решения обратной задачи с использованием случайных проекций. «Knowledge-Dialogue-Solution» (KDS-2 2009) : материалы XV Международной конференции. Киев, Украина, 2009. С. 93-98].

3. Durrant R.J., Kaban A., 2015. "Random projections as regularizers: learning a linear discriminant from fewer observations than dimensions”, Machine Learning, 99 (2), pp. 257-286. DOI: 10.1007/s10994-014-5466-8.

4. Durrant R. J., Kaban A., 2010. "Compressed Fisher Linear Discriminant Analysis: Classification of Randomly Projected Data", Proceedings of the 16th ACM SIGKDD International Conference on Knowledge Discovery and Data Mining (KDD 2010), Washington, DC, USA, July 25-28, 2010. DOI: 10.1145/1835804.1835945.

5. Xiang H., Zou J., 2013. "Regularization with randomized SVD for large-scale discrete inverse problems", Inverse Problems, 29 (8), 085008. DOI: 10.1088/0266-5611/29/8/085008.

6. Xiang H., Zou J., 2015. "Randomized algorithms for large-scale inverse problems with general Tikhonov regularizations", Inverse Problems, 31 (8), 085008, pp. 1-24. DOI: 10.1088/0266-5611/31/8/085008.

7. Wei Y., Xie P., Zhang L., 2016. "Tikhonov regularization and randomized GSVD", SIAM Journal on Matrix Analysis and Applications, 37 (2), pp. 649-675. DOI: 10.1137/15M1030200.

8. Hansen P., 1998. Rank-deficient and discrete ill-posed problems: Numerical aspects of linear inversion, SIAM, Philadelphia, $247 \mathrm{p}$.

9. Tikhonov A.N., Arsenin V.Ya., 1977. Solution of ill-posed problems, V. H. Winston \& Sons, Washington DC; J. Wiley, New York, $231 \mathrm{p}$.

10. Hansen P. C., 1987. "The truncatedSVD as a method for regularization”, BIT Numerical Mathematics, 27, pp. 534-553. DOI: $10.1007 / \mathrm{BF} 01937276$.

11. Revunova Ye.G., Tyshcuk A.V., 2014. "Model Selection Criterion for the Solution of Discrete Ill-Posed Problems Based on Singular Value Decomposition”, Control Systems and Computers, 6, pp. 3-11. (In Russian). [Ревунова Е. Г., Тищук А. В. Критерий выбора модели для решения дискретных некорректных задач на основе сингулярного разложения. Управляющие системы и машины. 2014. № 6. С. 3-11].

12. Revunova E.G., Tyshchuk A.V., 2015. "A model selection criterion for solution of discrete ill-posed problems based on the singular value decomposition”, Proceedings of the 7th International Workshop on Inductive Modelling (IWIM'2015), (Kyiv-Zhukin, 20-24th of July, 2015), Kyiv-Zhukyn, pp. 43-47.

13. Revunova E.G., Tishchuk A.V., Desyaterik A.A., 2015. "Kriterii vybora modeli dlya resheniya diskretnykh nekorrektnykh zadach na osnove SVD i QR razlozheniy", Inductive modeling of complex systems, 7, pp. 232-239. (In Russian) [Ревунова Е. Г., Тищук А. В., Десятерик А. А. Критерии выбора модели для решения дискретных некорректных задач на основе SVD и QR разложений. Індуктивне моделювання складних систем. 2015. 7. С. 232-239].

14. Revunova E.G., 2010. "Issledovaniye sostavlyayushchikh oshibki dlya resheniya obratnoy zadachi s ispolzovaniyem sluchaynykh proyektsiy", Mathematical Machines and Systems, 4, pp. 33-42. (In Russian) [Ревунова Е. Г. Исследование составляющих ошибки для решения обратной задачи с использованием случайных проекций. Математические машины и системы. 2010. 4. С. 33-42].

15. Rachkovskiy D.A., Revunova E.G., 2012. "Randomized method for solving discrete ill-posed problems", Cybernetics and Systems Analysis, 48 (4), pp. 621-635.

16. Revunova E.G., Rachkovskiy D.A., 2012. "Stable transformation of a linear system output to the output of system with a given basis by random projections", Proceedings of the 5th Int. Workshop on Inductive Modelling (IWIM'2012), Kyiv, pp. 37-41.

17. Revunova E.G., 2013. "Randomization approach to the reconstruction of signals resulted from indirect measurements", Proceedings of the 4th International Conference on Inductive Modelling (ICIM'2013), Kyiv, pp. 203-208.

18. Revunova E.G., 2016. "Model selection criteria for a linear model to solve discrete ill-posed problems on the basis of singular decomposition and random projection", Cybernetics and Systems Analysis, 52 (4), pp. 647-664. DOI: 10.1007/ s10559-016-9868-4.

19. Revunova E.G., 2015. "Analytical study of the error components for the solution of discrete ill-posed problems using random projections", Cybernetics and Systems Analysis, 51 (6), pp. 978-991. 
20. Revunova E.G., 2017. "Averaging over matrices in solving discrete ill-posed problems on the basis of random projection", Proceedings of the 12th International Scientific and Technical Conference on Computer Sciences and Information Technologies (CSIT’17) (Lviv, Ukraine, 5-8 Sept., 2017), 1, pp. 473-478. DOI: 10.1109/STC-CSIT.2017.8098831.

21. Revunova E.G., 2017. "Solution of the Discrete ill-posed problem on the basis of singular value decomposition and random projection", Advances in Intelligent Systems and Computing II, Springer, Cham, pp. 434-449.

22. Hansen P.C., Nagy J. G., Leary D. P., 2006. Deblurring Images : Matrices, Spectra and Filtering, SIAM.

23. Hansen P.C., 1994. "Regularization Tools: A Matlab package for analysis and solution of discrete ill-posed problems", Numer. Algorithms, 6 (1), pp. 1-35. DOI: 10.1007/BF02149761.

24. Rachkovskiy D.A., Revunova E.G., 2009. "Intelligent gamma-ray data processing for environmental monitoring”, Intelligent data analysis in global monitoring for environment and security, ITHEA, Kiev-Sofia, pp. 124-145.

Received 29.11.2021

О.Г. Ревунова, д.т.н., старший науковий співробітник, Міжнародний науково-навчальний центр інформаційних технологій та систем НАН та МОН України, 03187, м. Київ, просп. Академіка Глушкова, 40, Україна, egrevunova@gmail.com

O.B. Тищук, Провідний інженер-програміст, Roku Inc., м. Київ, Україна, avtyshcuk@gmail.com

o.O. Десятирик, кандидат фізико-математичних наук, асистент, Київський національний університет імені Тараса Шевченка, 03127, м. Київ, просп. Академіка Глушкова, 4Е, sasha.desyaterik@gmail.com

\section{УЗАГАЛЬНЕННЯ МЕТОДУ ВИПАДКОВИХ ПРОЄКЦІЙ ДЛЯ ЗАДАЧ ВІДНОВЛЕННЯ СИГНАЛІВ, ЩО ОПИСУЮТЬСЯ МОДЕЛЯМИ НА ОСНОВІ ЗГОРТКИ}

Вступ. У технічних системах часто зустрічається ситуація, коли перетворення вхід-вихід описується інтегральним рівнянням типу згортки (описується згорткою). Така ситуація виникає при відновленні сигналу об'єкта за результатами дистанційних вимірювань: наприклад, у задачах спектрометрії, при усуненні розмиття зображення тощо. Матриці дискретного подання сигналу виходу і ядра згортки (функції спотворення точки) відомі, потрібно знайти матрицю дискретного подання сигналу об'єкта. Відомий підхід до розв'язання цієї задачі включає наступні кроки: подання матриці ядра згортки у вигляді твору Кронекера, запис перетворення вхід-вихід з використанням матриць твору Кронекера, відшукання матриці дискретного уявлення сигналу об'єкта.

Оцінка матриці сигналу об'єкта, отримана з використанням обернених матриць розкладання Кронекера, є нестійкою. Нестійкість оцінювання матриці сигналу об'єкта з використанням матриць розкладання Кронекера пов'язана з тим, що вони мають властивості матриць дискретної некоректної задачі (число обумовленості велике, ряд сингулярних значень плавно спадає до нуля).

Для розв'язання дискретних некоректних завдань нами розроблено методи на основі випадкового проєктування, та випадкового проєктування з усередненням за випадковими матрицями, що забезпечують стійкий розв'язок з малою обчислювальною складністю.

Для розв'язання задач відновлення сигналів об'єкта в системах, де перетворення вхід-вихід описується інтегральним рівнянням типу згортки, потрібно узагальнити підхід регуляризації зворотної задачі на основі випадкових проєкцій на випадок двовимірних вхідних сигналів.

Ціль. Розробка стійкого методу відновлення сигналу об'єкта для випадку, коли перетворення вхід-вихід описується інтегральним рівнянням типу згортки.

Результати та висновки. Розроблено метод стійкого відновлення сигналу об'єкта для випадку, коли перетворення вхід-вихід описується інтегральним рівнянням типу згортки. Отримання стійкої оцінки сигналу об'єкта забезпечується за рахунок розкладання Кронекера матриці ядра згортки, обчислення випадкових проєкцій для матриць факторизації Кронекера та вибору оптимальної розмірності матриці проєктора. Робота методу проілюстрована застосуванням у технічних системах.

Перспективи. Напрямом подальших досліджень є розвиток методів вибору оптимальної розмірності матриці проєктора.

Ключові слова: дискретна некоректна задача, згортка, регуляризація, випадкове проєктування. 